\title{
Proposed Strategy for Egypt's shipping sector to integrate with Global Racing
}

\author{
By \\ Dr. Sherif Maher Osman Heakel ${ }^{1}$
}

' Associate professor of Ports \&Shipping Management, vice Dean of Continuing Education college-Alexandria Branch, Arab Academy for Science and Technology and Maritime Transport.

$T e l,+201001744790$

E-mail: shsml4@)hormail.com 


\section{Proposed Strategy for Egypt's shipping sector \\ to integrate with Global Racing}

\section{$\underline{\text { Abstract }}$}

Shipping represents one of the largest Imports and export industries, offering deep sea shipping services between the universes, as easily as in cross trades between third countries.

Shipping is present in all segments of the sector in all regions of the planet. Transfer of load and passengers at sea generate a net contribution to the country's balance of payments. In terms of added value, maritime sectors represent a percentage of the entire GDP of the countries. More or less $70 \%$ of shipping related jobs are onshore - in shipbuilding, naval architecture, scientific study, technology, electronics, cargo-handling and logistics.

This paper introduces an analysis the Egyptian shipping and the relevant remedies. Based on insights from institutional economics, improve transportation in Egypt is identified.

Keywords: Hinterland transport; coordination; seaports; Port Said; Egypt institutional economics. 


\section{1- Introduction:}

An efficient maritime transportation system is essential for Egypt's prosperity, having significant impacts on economic growth, societal development and the environment.

Egypt has a unique location consists of the center location bounded by the coasts of Europe, Africa and Asia gathers the three continentals combined with the Mediterranean Sea and the Red sea. Considering the mixture between the land and the industry to develop a new naturalistic approach helps public and private sector to achieve practical, innovative, efficient and efficacious for the river Nile transportation combined with the associated activities, centering in the human nature, labor force and inland waterway characteristics.

International maritime transport will face challenges in the coming years. This work has included the conduct of a prospective study analyzing trends and signals of change in Egypt's maritime sector.

The most urgent issues to be addressed and on the way the Egyptians could intervene in these developments are as follows:

- By 2024, Egyptian shipping transport services should be at least as effective, authentic and sustainable not as today. Hinterland capacitors should be capable to cope with increased cargo volumes.

- By 2024, the shipping industry should be at least as competitive as today, and assume an equally strong or more honorable place in the worldwide markets.

\section{1-1 Research Problem:}

Maritime transport is facing a new and complex environment that calls for both challenges and expectations. Of all the prevailing challenges, all the same, the interconnected issues of energy security and costs, climate change, and environmental sustainability are perhaps the most unsettling. Submitting to the opportunities, which Egypt can utilize to grab up the quick development of global transport business, these include - to cite just a few - deeper regional integration, cooperation;

Growing diversification of sources of preparation; and access to new markets, facilitated by cooperation agreements. And by improved transport networks (for example the Suez canal as a logistics center). 
In today's interdependent and globalized world, efficient and costeffective transportation systems that link global supply chains are the engine fuelling economic growth and prosperity. With 80 per cent of global merchandise trade by volume carried by sea and handled by ports worldwide, the strategic economic importance of maritime transport as a trade enabler cannot be overemphasized. The trade competitiveness of all countries-- developed and developing alike, and including landlocked countries - depends to a great extent on effective access to international shipping services and port networks.

Therefore, this research seeks to resolve the inquiry, how Egypt can rehab its maritime sector to capture these changes by suitable strategies to its today's political and Economical situations.

\section{1-2 Objectives of the study:}

While the reorientation of global output and trade continues, with developing countries contributing larger shares to world economic output and business deal. Egypt's performance of the worldwide economy and merchandise trade is believed to be really feeble. Thius, a high degree of global economic integration and interdependence of Egypt's maritime sector is required.

The aim of this paper is to investigate the Egypt's shipping unreliability and its impact on the hinterland supply chain. The report is coordinated as follows: in the following segment, an overview, is provided of the various factors causing unreliability in today's Egypt's shipping strategy. Specific attention is paid to the development of demand for container services and provision of container-handling capacity. Side by side, we look into the implications of recommended strategies for various participants throughout the supply chain, that is, transport lines, terminal operators, inland transport operators and shippers/consignees. The final section contains the main conclusions of the report and outlines some avenues for further inquiry.

So, this research seeks to answer the research problem by finding strategies to better integration of Egypt's maritime transport sector the international transport chains with its recent developments in the worldwide supply chain. 


\section{1-3 Methodology:}

Stranded in the nature and the purpose of this study, the qualitative method applies to the project work based on the essay format. Hence the study based mainly on desk study.

\section{1-4 Literature Review:}

The research depends on desk study, so many literatures are reviewed as referenced, but there are some basic literature, which inspire the researcher to come upward with this question. Examples are as follow:

Notteboom, T and Winkelmans W. $2004^{2}$, as their research divided into two parts. In part 1 key market developments in trade and logistics are identified. Part 2 attempts to analyse how the economic and logistics trends as described in part 1 affect European ports. The perspective is that of the European port system as a whole. This report gives a bird's eye view on the economic and logistics market developments affecting European seaports. The focus of port competition is gradually changing, so are the roles of the various stakeholders involved. The current issues port managers are facing are multiple and complex. The global masket place, with powerful and relatively footloose players, extensive business networks and complex logistics systems creates a high degree of uncertainty in the European port industry and leaves European port managers puzzled with the question how to respond effectively to market dynamics.

Also, Robinson, R. $2002^{3}$, concluded that Ports are also source of value creation for the firms involved in the process of services production.

In the mean time Notteboom, TE and Rodrigue, JP. $2005^{4}$ highlited that the regionalization phase and associated hinterland concepts demand

\footnotetext{
${ }^{2}$ Notteboom, T and Winkelmans, W. 2004: Factual ieport on the European port sector: FR-WPI: Overall market dynamics and their influence on the port sector. European Sea Ports Organization (ESPO): Brussels.

${ }^{3}$ Robinson, R. 2002: Ports as elements in value-driven chain systems: The new paradigm. Maritime Policy \& Management 29: $241--255$.
}

\footnotetext{
"Notteboon, TE and Rodrigue. IP. 2005: Port regionalization: Towards a new phase in port development. Maritine Policy \& Management 32: 297-313.
} 
new approaches to port governance and a functional focus that goes beyond the traditional port perimeter. The paper furthermore elaborates on governance issues linked to the regionalization phase and the development of sustainable hinterland concepts that add to a port's competitive position. The research concluded that Direct and indirect forms of networking with nodes and market players constitute probably the most important role for port authorities in the regionalization phase, as gaining competitive advantage will more and more become a matter of going beyond the port boundaries both in terms of physical investments and managerial capabilities.

Groothedde, B. $2005^{5}$ demonstrate the unequal distribution of the costs and benfits, the lack of resources or willingness to invest of at least one relevant firm,strategic considerations of infrastructure users and lack of supply chain power.

Nooteboom, B. $2004^{6}$ book, which could be used as main text in case on inter-firm alliances and networks, and as a supplementary text in courses on organizational, strategy, innovation, international business andeconomic geography. This book is intended as "both text book for advanced level of teaching and monography. The book takes an integrated approach combining issues of competence and governace,efficiency and learning strategy and organization.

\section{2- Unreliability in today's Egypt's shipping strategy:}

For Egypt, shipping has a humble contribution to economic growth and prosperity all along its history. At the start of the 21 st century, the maritime transport system is at the back front of the globalization process and hasn't provided the vehicle for an unprecedented growth of world trade and industrial and commercial interconnections in the world economic system.

Shipping services, including offshore activities, are all important for helping Egypt's companies compete globally. Among Arab's nations, short sea shipping is a key ingredient in reducing congestion, ensuring territorial cohesion and raising the sustainable growth of the Arab's continent.

${ }^{5}$ Groothedde, B. 2005: Collaborative logistics and transit networks: A modeling approach to bub network design. Trail-Thesis Series T2005/15, Trail, Delft.

${ }^{6}$ Nooteboom, B. 2004: Inter-firm collaboration, learning and networks: An integrated approach. Routledge: London. 
Egypt's Transport sector mission is "To build a world class integrated multimodal transport Infrastructure and services which satisfies people and business needs and demand as well as enabling Economic growth and sustainable growth in Egypt. "

ALSO, the strategic national objectives is to:

" $\square$ Maximize the economic returns of state of the transport sector.

$\square$ Promote National and International Investments.

$\square$ Build Knowledge to the Transport sector and transfer know how.

$\square$ Adopt new policies for PSO obligations"

Although, the mission and objectives are slightly light, but it directed toward shipping rehabilitation. It calls for a broader development strategy and aims to reach a bigger integration with worldwide logistics.

The success of Egypt's shipping in world markets cannot be got for granted. A ton of the major challenges has been sorted out:

- The current crisis of the Egypt's financial system, its impact on the real economy and the sluggish recovery prospects in different regions of the state have affected seaborne trade and therefore the different arms of the shipping industry (cargo-ships-ports).

- Moreover, recent developments in the energy markets, letting in the cult of pipelines for gas supplies, have emphasized the strategic importance of LNG tanker-ships for ensuring a stable and longterm solution to ensure reliable energy supplies from Egypt. In a fuller setting, those developments remind the importance of the fleet, in all its branches of activity, for the well being of the Egyptian citizens and of the Egypt's economy as a whole.

- Operators involved in the planning of maritime shipping services and the Egyptian maritime transport as such will face substantial challenges in the age to come. They will have to make do with the fluctuations in sea-borne trade,

- The negative impact of the fiscal crisis and other outside factors, such as the risk of overcapacity in certain market segments, the rise of protectionist measures affecting world trade, environmental concerns related to mood change, volatility in energy and other

${ }^{7}$ The previous source. 
commodities markets and loss of Egyptian maritime know-how because of the scarcity of skilled human resources.

\section{2-1 Egypt's shipping unreliability and its impact on the hinterland supply chain}

Understandably, the shipper's influence of port choice decisions is diminishing, especially now that a single shipping line, a third-party service supplier or a supply chain Integrator may control the shipment from the source to the final destination using various transport systems and multiple alternative pathways designed to minimize the total logistics cost and maximize value for both the client and the provider. With the progressive integration of ports in supply chains, it has become welldefined that shippers no longer rent a game per se, but rather a supply chain - a Computer software or bundle of logistics services; a pathway to markets - in which a factor is simply an element albeit an important one of the system. Still, amazingly, a routine of studies remains to focus on how a shopper selects a port in isolation of the chain systems in which it is planted.

Egypt's ports can be summed up as follows:

- " 15 commercial and 44 specialized ports (5 tourism, 11 petroleum, 7 mining and 21 fishing (5+17 Monitoring Point).

- Six ports on Mediterranean and nine on Red Sea.

- Alexandria Port, largest in Egypt, handling $60 \%$ of the country's foreign trade.

- East Port Said \& Damietta largest Container ports." 8

The development strategy in Egypt still executed on the basis of multi functional port, internal completion, and no concentration on one port for foreign cut throat competition. The best strategy from my point of sentiment is to focus on the two largest container ports in development for the purpose of foreign completion, trying to link them with hinterland for achieving multimodalism, and then apply logistics concepts. Putting in mind cost reduction "Economy of scale" in providing port's services.

Moreover, competitive advantages given to Egypt by Suez Canal existence in its primer coat and the prospective projects around the Suez Canal make shipping businesses entail a literal danger of de-localization

"http://ww/w.comcec.org/UserFiles/File/WorkingGroups/Transport2/Presentations/Muhammed_Cemale ttin-Egypt/COMCEC EGYPT.pdf 
of head offices and maritime industries outside Egypt. Often the spatial relation of Egyptian operators has been either not exists or undermined by unfair competition, which results from lax enforcement of safety, surety, environmental and social standards in Egypt. Achieving effective governance of maritime affairs and an international fair level playing area for maritime transport remains a crucial. challenge to Egypt's community.

Many different individual companies - shipping lines, terminal operating companies, forwarders, hinterland transport providers, and inland terminal operators - are involved in hinterland transport. To increase, different public actors such as the port authority, customs, and infrastructure managers are required. Creating effective hinterland transport chains requires the coordination between all these players. Coordination does not come about spontaneously; its growth may be hindered by free-riding problems, a lack of contractual relationships, information asymmetry, and a lack of incentives for cooperation.

These streams can easily be interchanged between different ports, which the same can apply along the Egyptian ports if the Egyptians use the opportunity of the Suez Canal passes through their country. Since container ports have become links in a global logistics chain", competition has moved from competition between ports to competition between transport chains. As a consequence, the ports are eager to raise the character of their hinterland transport services. Accordingly, if Egyptian ports are to win this competition, their hinterlands must reach the globalization level.

The purpose of a port's hinterland access depends on the demeanor of many players, including terminal operators (exist in Egypt), freight forwarders (only foreign companies), container operators (exist in Egypt), and the port authority (majority governmental). The judging takes a theoretical approach to raise understanding of the inter-organizational coordination.

Although coordination in maritime container transport has been extensively analyzed, primarily because of the on-going argument about the effects of cooperation in conferences and alliances (the modern pattern of conferences with the same rules). This research has led to a number of important concepts and findings (see, e.g. Notteboom and

${ }^{9}$ Robinson, R. 2002: Ports as elements in value-driven chain systems: The new paradigm. Maritime Policy \& Management 29: 241-255. 
Rodrigue, 2005). The special attention paid to coordination in container hinterland transport is surprising, given that hinterland-transport costs are generally higher than the maritime-transport costs, and that most bottlenecks in the door-to-door can occur in the Backcountry. Examples include congestion, inadequate rail infrastructure, problems with the handling of barges at deep-sea terminals, and the increased number of accidents along the Egyptian roads.

\section{3- Egypt's Maritime Transport strategies:}

"World container port throughput increased by an estimated 3.8 percent to 601.8 million 20-foot equivalent units in 2012. This growth was more downcast than the estimated 7.3 per cent increase of $201 \mathrm{l}$. This Growth is also pondered in a strong port finance sector as investors look to infrastructure to provide long-term stable returns. This is paramount as a recent study forecast that developing countries will need annual investment of $\$ 18.8$ trillion in real terms by 2020 to To achieve even moderate levels of economic growth." 10

Although the container was an innovation initially applied for maritime transportation, the emergence of global supply chains has placed intense pressures to implement containerization over inland freight distribution systems. Box - containerized - logistics are increasingly challenged to administer with the ever-increasing time, dependability and price demands of global supply chains. Imbalances in trade flows and accessibility and capacity constraints are among some of the additions that are necessitating it to a larger extent and harder to glean the wider benefits of containerization.

Before The Egyptian revolution the transport policies were concentrating at only in one sided development of transport modes elements, for example shipping industry elements (ships-pots-cargo), the immersion was on port developments only and ignoring or paying little attention to the other two facets of this industry. This is from a micro point of mind, in the macro side, we hold not even ideas to link the different other transport industries.

This can be evidence to answer the voices in Egypt to carve up the maritime transport in a separate ministry. The fact is, Egypt needs only one ministry of shipping, therefore all the modes can be under its control, 
and the coordination among them become possible in a very strong connected hinterland with The Egyptian ports.

\section{3-1 Recommended strategies for various participants throughout the supply chain:}

- Even though all participants may agree that investments (including management involvement) are asked to improve Egypt's shipping industry, some households may not be able or willing to take part. This issue is especially relevant to coordination problems in The Egyptian shipping involving relatively small firms, which needs encouragements to develop themselves and create new work opportunities for youthful people.

This can be done only, if the government gives them the security of their investment, encourage them through facilitating their business without any obstacles and sharing with them the risk of investment. Even if the government's share reached to $50 \%$, under one condition is to leave the management practices to the private partners without interference in any way from the government side. And give them the license to create alliances or cooperation among the private companies with full support to their requirements to do so.

The lack of a national firm with supply chain power will have a major impact on the structure of a transport chain (see e.g. Groothedde, 2005) ${ }^{11}$. A lack of supply chain power in Egypt reduces coordination. Her researchers can suggest a new firm existence from different investors including the government without intervention or affect on the board of directors of such firm.

"Egypt's Imports reached in 2011/2012 LE. 58 Billion and exports LE. 26 Billion, Volume of domestic freight in Egypt almost $500 \mathrm{~m}$ tons. Although Egypt has diversified transport modes, still 95\% of Egypt's freight moved only through the Roads and the rest is moved through the river and railways. Egypt has diversified transport modes and infrastructure which can support Egypt in implementing MFT in domestic and regional development." ${ }^{, 12}$ This point of view, the researcher has

\footnotetext{
"Groothedde, B. 2005: Collaborative logistics and transportation networks: A modeling approach to hub network design. Trail-Thesis Series T2005/15, Trail, Delft.

${ }^{12}$ hutp://www.comcec.org/UserFiles/File/WorkingGroups/Transport2/Presentations/Muhammed Cemal eltin-Egypt/COMCEC_ECYPT.pdf
} 
another one, which is to concentrate only on one mode of transport inside Egypt beside sea transport to achieve multimodal transport system.

Firms that expect the process of establishing better coordination through cooperation to be time-consuming and feel that results are uncertain may be reluctant to put any effort into this process. The most popular firms in Egypt are transport companies by roads, and the researchers point of views is the most suitable mode can co-ordinate with sea transport to apply door to door system, and this another issue needs a separate research.

These reasons explain why the efforts and investments those firms make to improve cooperation and coordination are in some cases limited. Firms often concentrate on internal issues and put less effort into resolving the coordination problems of the chain as a whole.

The most applicable example, in Egypt the international firms, which create offices in Egypt to execute the multimodal in the Egypt side or to apply the global logistics chain in Egypt side as well. If those international companies being attracted by The Egyptian government and share in enhancing the hinterland, they will benefit financially, increase their business volume, and the most important thing they will encourage investors and small firms to take the same path.

Consequently, Egypt will have its national firrns, and again more work opportunities in this sector. This attitude is more marked if actors expect cooperation to be difficult to achieve.

Thus, previous experience in coordination also determines a firm attitude (Nooteboom, 2004, p. 253) ${ }^{13}$. But this can be eliminated through The Egyptian government by convincing such firms and by giving them all the possible proof and transparency which will lead to success of this cooperation.

Beside that co-ordination mentioned previously can led to solving The Egyptian transport problems automatically.

Apart from the private actors who provide transportation and terminal services, which their number are very small and limited in Egypt, but

\footnotetext{
${ }^{13}$ Nooleboom, B. 2004: Inter-firm collaboration, learning and networks: An integrated approach.Routledge: London.
} 
there are several public actors are involved, such as customs, a port authority, inspection services, and infrastructure providers.

\section{$\underline{\text { 3-2 Strategic options towards Egypt's shipping Recovery }}$}

Several important conclusions come from this strategic review - exercise. First of all, the recovery of the Egypt's economy from the current financial crisis would lead to a growth in international trade and will require a maritime transport system able to deliver advanced logistic solutions. Moreover, in a recession period, short sea shipping is a perfect vehicle for stimulating intra-Arab trade exchanges and thus holding up recovery of growth in the Egypt and its neighboring states.

Overall, the next ten years may provide a singular chance to reinforce the competitiveness of Egyptian shipping, and to beef up its contribution to the aims of a sustainable Egypt transport policy.

The strategic recommendations for Egypt's shipping industry to integrate with the global racing concern seven main issues cited in the following section.

\section{3-2-1Competitive Egyptian shipping}

The priority is to attain and maintain an attractive framework for quality shipping and quality operators including financial criteria. This will help maritime transport achieve sustainable development goals. Such a framework would also facilitate the sector adapt to adverse financial conditions and to the slow-down in the ontogeny of the world's sea-borne trades.

\section{3-2-2 Human Factor}

There is a genuine Egyptian interest in making maritime professions more attractive to youthful people and thus improving employment of seamen. Positive measures may include facilitating lifelong career prospects in the maritime clusters; enhancing the image of shipping; supporting the study of international organizations (IMO and ILO) on fair treatment of seamen; and implementing simplification measures which target at reducing the administrative burden on masters and senior ship officers. 


\section{3-2-3 Greener Maritime Transport}

The Egypt's government should encourage all actors to promote green solutions in maritime shipping.

\section{3-2-4 A secure and secure system}

We should give precedence to the enforcement of existing Community and international principles and the speedy implementation of measures brought out with the 3rd maritime safety package. The work already started should be completed by establishing a comprehensive theoretical account for security bars in terms of prevention, response capability and resilience.

\section{3-2-5 International Scene}

The global challenges faced by the shipping and maritime industries demand convincing answers from the international community. The Commission and the Member States may be a real driving power for change towards a comprehensive international regulatory framework for shipping, adapted to the challenges of the 21 st century.

\section{3-2-6 Short Sea Shipping and Ports}

Further economic integration of the Arab Member States and of the neighboring countries will engage in a positive impact on maritime transport connections within the Arab nations. It should be noted that sea-trade normally grows even in periods of business contraction. In the 2018 horizon, the Egypt's economy should recover from the current doldrums. Positive steps in support of short sea shipping should also help intensify sea-exchanges in all the Egyptian maritime façades. These bills will include the presentation of an Egyptian Maritime Transport Space without Barriers the full deployment of the Motorways of the seas, but besides the execution of criteria for port investment and operation. In solid cases, the principles of open markets, honest competition and greening transport should be observed.

\section{3-2-7 First appearance and technical development}

The competitiveness of the Egyptian maritime industries and their capacity to meet the environmental, energy, safety and human challenges are positively determined by increased efforts in research 
and innovation. A theoretical account of the character should be introduced for the deployment of "e-Maritime" services at Egyptian and global stages.

\section{4- CONCLUSIONS}

This paper argues for the need to analyze Egypt's maritime industry and suitable strategies for its growth in the next $10 \mathrm{yr}$ :

first, because Egypt needs to solve many problems in Transport industry and needs to enter the global racing (Shipping-Ports-International transport and logistics).Second, because costs for hinterland transport are generally higher than the maritime transport costs; Third, because most bottlenecks of the door-to-door container transport chain, such as congestion, insufficient infrastructure, and problems with handling of barges or using river Nile, trains, and trucks at deep-sea terminals, occur in the Egyptian hinterland network.

This work promotes the present body of knowledge of Egypt's shipping. By identifying problems and proposing a framework inside which to study these problems.

In general, Maritime transport problems in Egypt turn out because of an asymmetry between the monetary values and benefits of coordination, a lack of willingness to invest, the strategic considerations of the workers involved, and risk-averse behavior.

Egypt in Transition period of time, and requires a new scientific and sharing of Expertise (Militaries or civilian) policy, that's why Researchers Decide to submit this paper for "The Egyptian New Transport Policy in the next 10 years.

A collective action arrangement is needed either on a micro or macro basis. In micro basis, the researchers suggest Examples arrangements as recommendations for restructuring the Transport sector in Egypt. Some examples are as follows:

- Formulate the Egyptian associations for transport companies, including all modes of transport (Maritime-Railways-TruckingInland (Barges).

- Formulate The Egyptian cluster association, and the port authorities are active in bringing about collective action. There are about 
Egypt today is in need for that because of having the private sector in some of the Egyptian ports. On a macro basis, Egypt has to arrive at a full bargain agreement with its neighboring nations, especially evolution of short sea trade.

These agreements can pass over a solid range of forms of cooperation between independent firms, through transport capacity pools, freight exchange websites, train shuttles, and thus onward.

In conclusion, an important event in Egypt nowadays Transport problems, and can be worked out during the following 10 years, which is The Egyptian ports and their hinterland access can be solutions for the whole transport sector. Ports and their hinterland transport systems can only draw and manage additional container volumes if the hinterland transport network is organized efficiently and efficaciously.

This inquiry provides a strong foundation for further inquiry. Additional research is needed to determine more precisely under what conditions a certain coordination mechanism is preferred. The framework proposed deserves further theoretical and empirical testing. Another promising sign.

A line of research would be to carry out the same analysis in other shipping sectors in Egypt (Each one of its own). Another thing worth investigating is whether there exists a relationship between Egypt's shipping elements and global supply chain. 


\section{REFERENCES:}

1. Cease, RH. 1937: The nature of the firm. Economics 4: 386-405.

2. Coase, RH. 1960: The problem of social cost. Journal of Law and Economics 3: 1-44.

3. De Langen, PW and Chouly, A. 2004: Hinterland access regimes in seaports. European Journal of Goods: A study of the possibilities of a high quality intermodal transport concept. Transport Policy 3.

4. Groothedde, B. 2005: Collaborative logistics and transportation networks: A modeling approach to hub network design. Trail-Thesis Series T2005/15, Trail, Delft.

5. Halldorsson, A, Kotzab, H, Mikkola, JH and Skjott-Larsen, T. 2005: How inter-organizational theories contribute to supply chain management, theoretical basis and application. In: De Koster, R and Delfmann, W (Eds) Supply Chain Management in European Perspective. Copenhagen Business.

6. Konings, JW. 1996: Integrated centers for the transshipment, storage, aggregation and distribution of Konings, JW. 2005: Foldable containers to boil down the prices of empty tape drive? A cost-benefit analysis from a Chain and multi-actor perspective. Maritime Economics and Logistics 7: 223.

7. Maher, Sherif. 2006: The purpose of third world countries ports from logistics globalization. Port training institute conference- AASTMTEgypt.

8. Maritime Economics \& Logistics, 2008, 10, (108-129),www.palgravejournals.com/mel

9. Nooteboom, B. 1992: Towards a dynamic theory of transactions. Journal of Evolutionary Economics 2:281-299.

10. Nooteboom, B. 2004: Inter-firm collaboration, learning and networks: An integrated approach. Routledge: London.

11.Notteboom, T and Winkelmans, W. 2004: Factual report on the European port sector: FR-WP1: Overall market dynamics and their influence on the port sector. European Sea Ports Organisation (ESPO): Brussels.

12.Notteboom, $T$ and Winkelmans, W. 2004: Factual report on the European port sector: FR-WPI: Overall market dynamics and their influence on the port sector. European Sea Ports Organisation (ESPO): Brussels.

13. Notteboom, TE and Rodrigue, JP. 2005: Port regionalization: Towards a new phase in port development. Maritime Policy \& Management 32: 297-313. 
14.Panayides, PM. 2002: Economic organization of intermodal shipping. Transport Reviews 22: 401-404.

15.REVIEW OF MARITIME TRANSPORT 2013

16.Robinson, R. 2002: Ports as elements in value-driven chain systems: The new paradigm. Maritime Policy \& Management 29: 241-255.

17.School: Copenhagen. Transport and Infrastructure Research 4: 361-380

18. Williamson, OE. 1975: Markets and hierarchies. MacMillan: New York.

19.Williamson, OE. 1996: The mechanisms of administration. Oxford University Press: New York. 3-11.

\section{Websights:}

20.http://www.comcec.org/UserFiles/File/WorkingGroups/Transport2/Presentations/Mu . hammed_Cemalettin-Egypt/COMCEC EGYPT.pdf 